\title{
Systolic blood pressure and heart rate in cats with chronic kidney disease undergoing chemical restraint during hemodialysis
}

\author{
Avaliação da pressão arterial sistólica sistêmica e frequência \\ cardíaca em gatos com doença renal crônica, submetidos à \\ contenção química durante hemodiálise
}

\author{
Karine Kleine Figueiredo dos Santos ${ }^{1 *}$; Daniel Paulino Junior²; \\ Julio César Cambraia Veado ${ }^{3}$; Juliana de Abreu Pereira ${ }^{4}$
}

\begin{abstract}
Dialysis is one of the used methods for treatment of Acute Renal Injury (ARI) and Chronic Kidney Disease (CKD) to replace the function of the kidneys when refers to blood depuration. Hemodialysis removes toxins accumulated in the body directly from the blood, being a useful alternative therapy for dogs and cats with CKD in advanced stages. Because of the difficulty on handling the patient feline, this procedure requires sedation. However, few studies have been conducted to assess the safety of anesthesia in dogs and cats with CKD undergoing dialysis. The present study aimed to evaluate two different protocols of chemical restraint in cats with CKD and the effect of these on systolic blood pressure (SBP) and heart rate (HR), since the procedure of extracorporeal circulation leads the patient to a hypotensive frame. Twelve adult cats were used, with an average weight of $4 \mathrm{~kg}, \mathrm{CKD}$, underwent two anesthetic protocols: Group GP $(n=6)$ using propofol, and group GCM $(n=6)$ using ketamine-midazolam association for the implantation procedure of central venous catheter (CVC) and hemodialysis. Cats in GP as well as the GCM group showed statistical difference in the change in SBP and HR only from baseline compared to the other time points evaluated. The two protocols maintained SBP and HR within physiological values.
\end{abstract}

Key words: Feline. Dialysis. Sedation.

\section{Resumo}

Hemodiálise (HD) é um método que pode ser utilizado de forma adjuvante, no tratamento da Injúria Renal Aguda (IRA) e Doença Renal Crônica (DRC), sendo capaz de substituir as funções excretora, de equilíbrio hidroeletrolítico e ácido-base dos rins. Pela dificuldade de manipulação do paciente felino, para realização de hemodiálise, muitas vezes é necessário submetê-lo ao efeito de substâncias anestésicas. Contudo, poucos estudos foram realizados no sentido de avaliar a segurança, de cães e gatos com DRC, submetidos à hemodiálise. O presente estudo teve por objetivo avaliar dois protocolos de contenção química em felinos portadores de DRC e seus efeitos sobre a pressão arterial sistólica (PAS) e frequência cardíaca (FC), uma vez que o procedimento de circulação extracorpórea conduz o

${ }^{1}$ Discente do Curso de Doutorado no Programa de Pós-Graduação em Clínica Médica, Universidade Federal do Rio de Janeiro, UFRJ, Rio de Janeiro, RJ, Brasil. E-mail: drakarinekleine@hotmail.com

2 Prof. Dr., Universidade de Franca, UNIFRAN, Franca, SP, Brasil. E-mail: danielcardio@unifran.br

${ }^{3}$ Prof. Associado I, Escola de Medicina Veterinária; Universidade Federal de Minas Gerais, UFMG, Belo Horizonte, MG, Brasil. E-mail: cambraia@ufmg.br

${ }^{4}$ Discente do Curso de Doutorado no Programa de Pós-Graduação em Medicina Veterinária, Patologia e Ciências Clínicas, Universidade Federal Rural do Rio de Janeiro, UFRRJ, Seropédica, RJ, Brasil. E-mail: julianabreu_vet@hotmail.com

* Author for correspondence 
paciente a um quadro hipotensor. Foram selecionados doze felinos, adultos, com peso médio de $4 \mathrm{Kg}$, portadores de DRC, submetidos a dois protocolos anestésicos, sendo divididos em dois grupos: Grupo Propofol (GP) com seis animais, utilizando propofol, e o Grupo Cetamina-Midazolan (GCM), também com seis animais, utilizando associação cetamina-midazolan. Os dois fármacos foram empregados com intuito de permitir implantação de catéter venoso central (CVC) e hemodiálise. Os felinos do grupo GP, assim como os do grupo GCM, apresentaram alteração com diferença significativa das PAS e FC entre o momento basal e os demais momentos avaliados. Os dois protocolos mantiveram a PAS e FC dentro de intervalos de referência de valores de normalidade para a espécie estudada, sendo considerados seguros para serem utilizados em pacientes portadores de DRC, submetidos à implantação de catéter venoso central e hemodiálise.

Palavras-chave: Felinos. Técnicas dialíticas. Sedação.

\section{Introduction}

Feline patients usually present hostile behavior when handled, which frequently leads to the requirement for chemical restraint (ANDRESS et al., 1995; ARAÚJO et al., 2001). Hemodialysis (HD) may be characterized as a long-lasting procedure, with an average duration from $45 \mathrm{~min}$ to $2 \mathrm{~h}$. In felines undergoing this procedure, it is necessary to use a restraining substance.

The aim of HD is to remove undesirable substances, water, and minerals from the bloodstream, through a plasma exchange system consisting of semipermeable, tubular, and hollow membranes contained in a capillary or dialyzer cartridge (VEADO, 2003). HD may be indicated in cases of acute renal injury, some decompensation conditions in chronic kidney disease (CKD), poisoning, intoxication, and hypervolemia (COWGILL; LANGSTONE, 1996). To implant a catheter in the external jugular vein, it is necessary to sedate the patient, mainly because of the skin surgical incision required for the catheter implantation (COWGILL; LANGSTONE, 1996).

Performing anesthesia in patients with $\mathrm{CKD}$ requires great care, especially if the patient presents disorders in several organ systems. HD is little practiced in felines, and, consequently, there are few veterinary studies that show the safety and risks of anesthesia induction in felines with CKD (PASCOE et al., 2006).
Among the anesthetic substances available in the market with proven efficacy, and applicable for use in feline species, is propofol, an ultra-shortterm anesthetic that is appropriate for sedation, besides inducing the anesthetic maintenance of volatile drugs (ANDERS et al., 2008). Propofol is eliminated by the kidneys after being converted into inactive metabolites (FANTONI et al., 2002; PADDLEFORD, 2001). The decreased concentrations of glucuronyltransferases in the hepatic metabolism of cats may be the cause of the slow recovery after continuous prolonged infusions of propofol (PASCOE et al., 2006).

The combination of ketamine, a dissociative anesthetic (VIANA, 2008), and midazolam, a benzodiazepine, produces an excellent tranquilizer/ anesthetic effect. This combination causes a slight decrease in the blood pressure (BP) values. Midazolam is eliminated through renal excretion, by metabolites linked to glucuronic acid (SPINOSA; GORNIAK, 1996). Owing to its effects of increased heart rate (HR), cardiac output, BP, left ventricular beats, and oxygen consumption by the myocardium, ketamine has been associated with sedatives or tranquilizers, in addition to eliminating or minimizing the adverse effects of benzodiazepine. The combination of ketamine and benzodiazepine provides greater safety, minimum depressive effects, and quick recovery from the anesthesia. In this study, we evaluated the effects of two anesthetic protocols (propofol and ketamine-midazolam 
combination) on systolic BP (SBP) and HR, during central venous catheter (CVC) implantation and HD in feline patients with CKD.

\section{Materials and Methods}

This study was approved by the Animal Ethics Committee of Unifran (protocol no. 016/13) on May 9, 2013.

A total of 12 adult felines, with an average weight of $4 \mathrm{~kg}$, were selected for this study (eight male and four female cats of different breeds, aged between 2 and 10 years, and classified as having CKD). All animals presented nonregenerative normocytic normochromic anemia and decreased serum albumin (2-5 $\left.\mathrm{mg} \mathrm{dL}^{-1}\right)$. Because of the presence of anemia, and to enable the dialysis procedure, all animals underwent blood transfusion (blood from a suitable donor; cross-matching test was performed), on the day before the experiment. A total of $50 \mathrm{~mL}$ blood was separated to fill out the extracorporeal circuit of the dialysis machine. The study animals met the following criteria: with satisfactory general clinical condition; presenting no symptoms of parasitic, infectious, metabolic, or neoplastic diseases, and with values of serum biochemical parameters indicative of kidney disease (urea and creatinine serum concentrations above the normal range for a period $>3$ months, or a clinical picture compatible with signs of degenerative processes); with signs of uremia; and patients from the clinical routine at Grupo Kleine Especialidades Veterinárias, Rio de Janeiro, RJ.

Twenty-one felines were assessed; however, only 12 were included in the study. Among the nine excluded animals, six were excluded for being aggressive, making impossible the measurement of the SBP at M0 (baseline). Two animals were excluded for not presenting sedation with the propofol dosage established for the study. One animal was excluded from the study for having not presented anaphylactic reaction after blood transfusion, even with the performance of a crossmatching test.

To implant the CVC for the HD procedure, the animals were randomly divided into two groups and subjected to two anesthetic protocols-propofol group (GP, $\mathrm{n}=6$ ): propofol at a dose of $2.5 \mathrm{mg}$ $\mathrm{kg}^{-1}$, intravenously, in bolus and single-dosage forms; ketamine-midazolam group (GCM, $\mathrm{n}=$ 6): ketamine-midazolam combination (5 mg kg-1 intravenous ketamine and $0.2 \mathrm{mg} \mathrm{kg}^{-1}$ intramuscular midazolam, single dosage).

The SBP was measured before chemical restraint (M0), 5 minutes ( $\mathrm{min}$ ) after the drug administrations (M1), 5 min after the start of HD (M2), and 5 min after the end of HD (M3). The procedure was conducted by using a sphygmomanometer and vascular Doppler $\left(\right.$ Microem $^{\circledR}$; Doppler Fetal Microem, São Paulo, Brazil), which is characterized as a noninvasive method.

The CVC was implanted after applying the anesthetic and tranquilizer drugs described in the protocol of this experiment, and the anesthetic plans were evaluated according to the procedure described by Selmi et al. (2005): observation of the animal's mandible relaxation, third eyelid protrusion, incapacity of supporting the neck, and reduction of the eyelids' reflex intensity. When these signs were observed, the skin incision for the catheter implantation into the external jugular was made. Vascular access was achieved through the implantation of a 6-Fr dual-lumen catheter (Intra Special Catheters $\mathrm{GmbH}^{\circledR}$, Germany, 2002). Antisepsis was performed, and asepsis was maintained throughout the study, in order to avoid contaminations. In addition, a local bandage with gauze and adhesive plaster was placed over the implantation area for its protection. Then, $15 \mathrm{~min}$ after the catheter implantation, the HD procedure was started by using a device intended for human HD (Baxter ${ }^{\circledR}, 1550$ model, United States, 1998). The procedure lasted around $45 \mathrm{~min}$. The dialyzer used has a surface area of $2 \mathrm{~m}^{2}$ (F3 model, Fresenius 
Medical Care ${ }^{\circledR}$, Germany, 2013). The extracorporeal blood circulation system was assembled by using neonatal model bloodlines (Fresenius). Systemic anticoagulation was obtained through direct administration of heparin (50 UI/ $/ \mathrm{kg}$, intravenously) to the bloodlines at the start of the procedure. The circuit formed by the bloodlines and the dialyzer were partially filled out with $50 \mathrm{~mL}$ blood, which came from the same donor as that on the day before blood transfusion, and physiological solution $(0.9 \%$ $\mathrm{NaCl})$. Solutions of bicarbonate and concentrated acid (Medical Fresenius Care ${ }^{\circledR}$, Germany, 2013) were used to produce artificial plasma.

To carry out the HD, the following order of procedures was followed: animal sedation; central venous catheter implantation; dialysis machine assembly with neonatal arterial and venous bloodlines, F3 dialyzer, and connection with bicarbonate and concentrated acid solutions; filling of arterial and venous bloodlines, with approximately $50 \mathrm{~mL}$ blood, and complementation of this system with a $0.9 \% \mathrm{NaCl}$ physiological solution; removal of all the air present in the extracorporeal circuit; and the performance of HD.

\section{Results and Discussion}

The results obtained in this research are shown as tables presenting the means and standard deviations of the studied variables. The SBP values for the patients of both groups, at different time points, are shown in Table 1. The HR values are shown in Table 2.

Table 1. Mean values and standard deviations (SDs) of systolic blood pressure (SBP) in cats that underwent two anesthetic protocols (propofol and ketamine-midazolam), measured before chemical restraint (M0), 5 min after the drug administrations (M1), 5 min before the start of hemodialysis (M2), and 5 minutes after the end of the hemodialysis procedure (M4).

\begin{tabular}{cccccccccc}
\hline Animal & \multicolumn{2}{c}{ Propofol, SBP } & \multicolumn{1}{c}{$\mathbf{m m} \mathbf{H g}]$} & $\mathbf{( G P )}$ & Animal & \multicolumn{4}{c}{ Ketamine + } \\
\hline & M0 & M1 & M2 & M3 & & M0 & M1 & M2 & M3 \\
$\mathbf{1}$ & 150 & 128 & 100 & 110 & 1 & 180 & 210 & 130 & 127 \\
$\mathbf{2}$ & 180 & 150 & 110 & 115 & 2 & 170 & 210 & 120 & 110 \\
$\mathbf{3}$ & 180 & 170 & 140 & 160 & 3 & 150 & 200 & 115 & 110 \\
$\mathbf{4}$ & 190 & 175 & 155 & 160 & 4 & 165 & 195 & 125 & 130 \\
$\mathbf{5}$ & 170 & 150 & 120 & 140 & 5 & 170 & 210 & 110 & 125 \\
$\mathbf{6}$ & 180 & 165 & 130 & 140 & 6 & 170 & 220 & 115 & 120 \\
Mean & 175 & 156.3 & 125.8 & 137.5 & & 167.5 & 207.5 & 119.2 & 120.3 \\
\pm & \pm & \pm & \pm & \pm & & \pm & \pm & \pm & \pm \\
SD & 3.9 & 17.3 & 20.1 & 21.4 & & 9.9 & 8.8 & 7.4 & 8.6 \\
\hline
\end{tabular}

The GP group presented a decrease in the SBP at all the evaluated time points, when compared with the baseline (M0), without presenting any effect caused by the drugs, in the nonparametric statistical analysis with the Tukey test. There was a statistical difference $(\mathrm{p}<0.05)$ between M0 and the other time points. There was no significant change $(\mathrm{p}>0.05)$ between M2 and M3. 
Table 2. Mean values and standard deviations (SDs) of heart rate (HR) in cats that underwent two anesthetic protocols (propofol and ketamine-midazolam), measured before chemical restraint (M0), 5 min after the drug administrations (M1), 5 min before the start of hemodialysis (M2), and 5 min after the end of the hemodialysis procedure (M4).

\begin{tabular}{|c|c|c|c|c|c|c|c|c|c|}
\hline \multirow[t]{2}{*}{ Animal } & \multicolumn{4}{|c|}{ Propofol, HR [bpm] (GP) } & \multirow[t]{2}{*}{ Animal } & \multicolumn{4}{|c|}{ Ketamine + midazolam, HR $[\mathrm{bpm}](\mathrm{GCM})$} \\
\hline & M0 & M1 & M2 & M3 & & M0 & M1 & M2 & M3 \\
\hline 1 & 175 & 190 & 165 & 165 & 1 & 165 & 184 & 150 & 155 \\
\hline 2 & 190 & 215 & 195 & 190 & 2 & 174 & 189 & 160 & 145 \\
\hline 3 & 185 & 214 & 160 & 175 & 3 & 180 & 205 & 180 & 176 \\
\hline 4 & 190 & 210 & 174 & 180 & 4 & 164 & 178 & 175 & 150 \\
\hline 5 & 165 & 183 & 150 & 164 & 5 & 175 & 190 & 160 & 162 \\
\hline 6 & 185 & 210 & 165 & 166 & 6 & 185 & 210 & 190 & 170 \\
\hline $\begin{array}{c}\text { Mean } \\
\pm\end{array}$ & $181.7 \pm$ & $203.7 \pm$ & $168.2 \pm$ & $173.3 \pm$ & $\begin{array}{c}\text { Mean } \\
\quad \pm\end{array}$ & $173.8 \pm$ & $192.7 \pm$ & $169.2 \pm$ & $159.7 \pm$ \\
\hline SD & 9.8 & 13.6 & 15.3 & 10.3 & $\mathrm{SD}$ & 8.2 & 12.4 & 14.9 & 11.9 \\
\hline
\end{tabular}

In the GCM group, there was an increase in the SBP after the anesthetic administration (M1), followed by the decrease in pressure at the other time points. There was a significant change between M0 and the other evaluated time points $(\mathrm{p}<0.05)$. There was no significant change $(\mathrm{p}>0.05)$ between M2 and M3.

The HR decreased after the induction with propofol; however, the values remained within the physiological range for the species.

Despite presenting an increase in HR after the drug administration, the HR values of the GCM group did not show any significant difference among the time points and between the groups.

Both groups presented a decrease in the urea serum value (approximately 33\% during the dialysis procedure). Furthermore, both groups presented a reduction in creatinine of approximately $40 \%$. The average of the values before HD was $340 \pm$ $124.95 \mathrm{mg} \mathrm{dL}^{-1}$ for urea and $7.63 \pm 3.52 \mathrm{mg} \mathrm{dL}^{-1}$ for creatinine; after HD, the values were $112.85 \pm$ $103.46 \mathrm{mg} \mathrm{dL}^{-1}$ for urea and $4.45 \pm 2.5 \mathrm{mg} \mathrm{dL}^{-1}$ for creatinine.

Although propofol is an ultra-short-term anesthesia, it was able to keep the animals of the GP group partially sedated, allowing the procedure to continue for approximately $30 \mathrm{~min}$, even though the dose applied was lower than that used by Pascoe et al. (2006). Felines have the biological difficulty of transforming propofol (ANDRESS et al., 1995; PASCOE et al., 2006), which explains the need for preserving the sedation, even partially, in animals undergoing dialysis. The high molecular weight of the propofol-albumin association by-product makes the dialysis of this product difficult and, consequently, causes difficulty in the excretion of the product through the dialysis capillary and the kidneys, which results in a long-lasting period of sedation compared with that with the ketaminmedazolam combination (JOY et al., 1997).

No change in the HR was observed during this experiment, similar to the findings of Selmi et al. (2005), Andress et al. (1995), and Araújo et al. (2001), who also used propofol in cats. In the study by Selmi et al. (2005), continuous infusion of propofol was done in cats premedicated with ketaminemidazolam; although the dosage used was lower than that used in this study, cardiopulmonary arrest or any other complication arising from anesthesia was not observed, similar to the results obtained in this study. During this anesthetic procedure, cardiovascular safety must be ensured through the administration of propofol in bolus form, as repeated and quick administrations of propofol can cause hypotension and apnea, which are undesirable but 
reversible effects. Concerning the $\mathrm{CMG}$ group, the mitigating or suppressing effect of midazolam on the ketamine-induced excessive increase in BP have allowed to conduct the experiment in felines, with no complication. Benzodiazepine may potentialize the central nervous system depressor effect when associated with barbiturates or propofol; however, it is necessary to adjust the dosage of these associated agents, in order to ensure the safety of the anesthetic procedure.

The results obtained from both groups showed that the HR and SBP values remained within the normal interval ranges, supporting the study of Castro (2010) who also used propofol and midazolam in cats, indicating that both tested protocols are sustainable for dialytic therapy.

Motta et al. (2010) described that in humans, drugs such as propofol and midazolam, among other drug associations, are used to promote sedation for the implantation of long-term transhepatic catheters for the performance of HD. This technique is prescribed for patients without other types of central venous access. The excessive handling of the CVC and its changes may lead to the blockage of the jugular, which is the access chosen for the implantation of long-term catheters in humans.

The implantation of long-term dual-lumen catheters in the external jugular vein, as the venous access for the performance of $\mathrm{HD}$, has shown effective results in dogs (MELCHERT et al., 2008). This study with cats obtained similar results, in which it was possible to conduct the same procedure with good blood flow and use of simple techniques for the implantation of the CVC into the jugular vein. In the study of Melchert et al. (2008), as in this experiment, no catheter contamination was described. The skin of the implantation area presented no signs of infection, although a culture procedure was not performed.

The low weight of the feline is a limiting factor in the use of the HD technique in this species; however, the neonatal, arterial, and venous bloodlines used for the extracorporeal circulation in the dialysis machine enabled the performance of the procedure. The animal's blood volume in the machine exceeded $20 \%$ of its total blood. The technique of filling the arterial and venous bloodlines with transfusion blood prevented the development of hypotension. This technique was also done successfully by Langstone et al. (1997).

\section{Conclusions}

Both protocols were considered suitable for the chemical restraint of animals undergoing HD therapy, as long as the hypotension and increase in HR due to the extracorporeal circulation system and the anesthetics or the chemical restraint drug have not interfered with the physiological status of the patient. Therefore, the dialysis procedure was considered suitable for the adjuvant treatment of uremia in felines, by using propofol and the combination of ketamine-midazolam, according to the studied protocols. Furthermore, the drugs, applied at the proposed dosage, have allowed the conduction of the HD procedures safely and with the preservation of the vital parameters within the normal intervals.

\section{References}

ANDERS, B. B.; HOELZLER, M. G.; SCAVELLI, T. D.; FULCHER, R. P.; BASTIAN, R. P. Analysis of auditory and neurologic effects associated with ventral bulla osteotomy for removal of inflammatory polyps or nasopharyngeal masses in cats. Journal of the American Veterinary Medical Association, Illinois, v. 233, n. 4, p. 580-585, 2008.

ANDRESS, J. L.; DAY, T. K.; DAY, D. G. The effects of consecutive day propofol anesthesia on feline red blood cells. Veterinary Surgery, Massachusetts, v. 24, n. 3, p. 277-282, 1995.

ARAÚJO, I. C.; POMPERMAYER, L. G.; ANTUNES, F.; SOUZA, A. P.; LOPES, M. A. F. Analgesic effect of butorphanol on somatic pain in cats anesthetized with propofol. Ciência Rural, Santa Maria, v. 31, n. 1, p. 6166, 2001. 
CASTRO, D. G. Efeitos do midazolam associado ao propofol, na indução da anestesia em gatas submetidas a ovariossalpingo-histerectomia. 2010. Dissertação (Mestrado em Clínica Cirúrgica Veterinária) - Faculdade de Medicina Veterinária e Zootecnia, Universidade de São Paulo, São Paulo.

COWGILL, L. D.; LANGSTONE, C. Role of hemodialysis in the management of dogs and cats with renal failure. Veterinary Clinics of North America: Small Animal Practice, Philadelphia, v. 26, n. 6, p. 1347-1378, 1996.

FANTONI, D. T. F.; CORTOPASSI, S. G.; BERNARDI, M. M. Anestésicos intravenosos e outros parenterais. In: SPINOSA, H. S.; GÓRNIAK, S. L.; BERNARDI, M. M. Farmacologia aplicada à Medicina Veterinária. 3. ed. São Paulo: Guanabara Koogan, 2002. p. 117-128.

JOY, A.; MOFFETT, J.; NEARY, K.; MORDECHAI, E.; STACHOWIAK, E. K.; COONS, S.; RANKINSHAPIRO, J.; FLORKIEWICZ, R. Z.; STACHOWIAK, M. K. Nuclear accumulation of FGF-2 is associated with proliferation of human astrocytes and glioma cells. Oncogene Journal, Tennesse, v. 14, n. 2, p. 171-183, 1997.

LANGSTONE, C.; COWGILL, L. D.; SPANO A. J. Applications and outcome of hemodialysis in cats a review of 29 cases. Journal of Veterinary Internal Medicine, Chichester, v. 11, n. 6, p. 348-355, 1997.

MELCHERT, I. A.; MENESES, A. M. C.; BRANT, J. R. A. C.; BALBI, A. L.; CARAMORI, J. T.; BARRETTI, P. Acesso vascular para hemodiálise com cateter temporário de duplo lúmen em cães com insuficiência renal aguda. Ciência Rural, Santa Maria, v. 38, n. 4, p. 1010-1016, 2008.
MOTTA, L. F. J. M.; CARNEVALE, C. F.; NASSER, F.; SOUZA, J. O. W.; ZURSTRASSEM, E. C.; MOREIRA, M. A.; AFFONSO, B. B.; CERRI, G. G. Acesso venoso trans-hepático percutâneo para hemodiálise: uma alternativa para pacientes portadores de insuficiência renal crônica. Jornal Vascular Brasileiro, Porto Alegre, v. 9, n. 3, p. 132-136, 2010.

PASCOE, P. J.; ILKIW, J. E.; FRISCHMEIER, K. J. The effect of the duration of propofol administration on recovery from anesthesia in cats. Veterinary Anaesthesia and Analgesia, Massachusetts, v. 33, p. 2-7, 2006.

SELMI, A. L.; FIGUEIREDO, J. P.; MENDES, G. M.; LAVOR, L. M. S.; MACHADO, P. M. L. Infusão continua de propofol em gatos pré-medicados com cetamina-midazolam. Arquivo Brasileiro de Medicina Veterinária e Zootecnia, Belo Horizonte, v. 57, n. 3, p. 295-299, 2005.

SPINOSA, H. S.; GORNIÁK, S. L. Tranquilizantes relaxantes musculares de ação central. In: SPINOSA, H. S; GORNIÁK, S. L.; BERNARDI, M. M. Farmacologia aplicada à medicina veterinária. 3. ed. Rio de Janeiro: Guanabara Koogan, 1996. p. 131-139.

VEADO, J. C. C. Hemodiálise - por que empregar a técnica em animais. MEDVEP: Revista Científica de Medicina Veterinária. Pequenos Animais e Animais de Estimação, Curitiba, v. 1, n. 1, p. 53-57, 2003.

PADDLEFORD, R. P. Manual de anestesia em pequenos animais. 2. ed. São Paulo: Roca, 2001. 423 p.

VIANA, F. A. B. Guia terapêutico veterinário. 2. ed. São Paulo: Editora Cem; 2008. 463 p. 
